DOI: $10.1355 / \mathrm{ae} 26-2 \mathrm{a}$

\title{
Exchange Rate Policy in Vietnam, 1985-2008
}

\author{
Nguyen Tran Phuc and Nguyen Duc-Tho
}

\begin{abstract}
In this paper we provide a review and synthesis of some of the available information and data regarding Vietnam's exchange rate regime, as well as an analysis of whether, and to what extent, the conduct of exchange rate policy has been consistent with a number of possible key policy objectives. To facilitate the analysis, annual and monthly data are compiled for both the nominal and real effective exchange rates (NEER and REER). The analysis suggests that the authorities have tended to place special emphasis on maintaining stability in the nominal, bilateral VND/USD exchange rate. As a consequence, there have been periods when the REER appreciated, indicating losses in international competitiveness. The official exchange rate's stability has also acted as a retardant in the development of the country's foreign exchange market. It appears that this stability has been neither necessary nor sufficient for inflation control.
\end{abstract}

Keywords: Vietnam, exchange rate policy, foreign exchange market, nominal and effective exchange rates, policy objectives.

\section{Introduction}

In an open economy, the exchange rate is typically one of the most important macroeconomic variables and exerts considerable influence over the inflation rate, international competitiveness and trade performance, financial stability, and the functioning of the foreign exchange market (Frieden, Ghezzi, and Stein 2001; Ho and McCauley 2003). In Vietnam, however, the exchange rate played a relatively low-key role under the central planning system, and only became central to economic policy-making after the mid-1980s, when sweeping economic reforms were first adopted. Since then, the exchange rate regime has gradually evolved from a system of multiple exchange rates to a single announced fixed rate, then to the current system incorporating a narrow adjustable band around the official rate, which is itself set on a daily basis and is meant to reflect the interaction of market forces.

Through these changes, has the exchange rate been managed in a way that generally contributed to the achievement of national economic objectives? It is difficult to address this question, partly because of the opaque nature of official information regarding the nature and relative 
importance of national policy objectives generally, and partly because of a relative dearth of rigorous, systematic studies of the relevant economic issues in the Vietnamese context.

International as well as domestic observers have frequently encouraged the Vietnamese authorities to allow greater flexibility in the exchange rate, as a means to manage external shocks more effectively and to preserve competitiveness on international markets (IMF 2006a, 2006b). It appears that the authorities have been reluctant to move more rapidly in that direction, perhaps due to other policy concerns.

It is of interest, therefore, to examine the data more closely and to assess whether the conduct of exchange rate policy in Vietnam has been conducive to the achievement of a range of economic policy objectives, including implicit ones. The purpose of this paper is to make a contribution in that regard, by presenting an analytical review of the country's exchange rate policy since 1985 and its implications. In particular, the paper will seek to identify some key economic objectives which may have been relevant in the context of Vietnam's economy during this period, and to assess the consistency of the actual conduct of exchange rate policy with the identified objectives.

We recognize that the list of economic objectives presented below is far from exhaustive. Moreover, to policy-makers at the time, noneconomic factors may have been just as important as economic considerations were, if not more so. Accordingly, we could start from a working hypothesis that, for example, political and/or ideological considerations continued to dominate after the launch of the economic reform process. Another plausible working hypothesis would be that a possible lack of familiarity with, and of confidence in, market mechanisms permeated many levels of policy-making, at least for some time. However, an in-depth historical analysis of the political economy of how and why specific policies were made during this period is beyond the scope of this paper.

Our purpose, instead, is to present a what-if economic analysis of the available facts and data. The questions we ask are: (i) Given the economic circumstances at the time, what would have been a reasonable set of economic policy objectives?

(ii) Has the conduct of exchange rate policy been conducive to the achievement of these objectives?

It is hoped that, within fairly tight space constraints, a reasonably comprehensive and selfcontained but also systematic and consistent analysis can be offered. If this aim can be realized, it will have been a non-trivial matter, as information and data in a developing country like Vietnam often come in an incomplete, fragmentary form from diverse sources which are at times inconsistent with one another - a problem particularly prevalent with Vietnameselanguage sources. The analysis may also be of interest from the viewpoint of other developing and transitional economies which have been grappling with similar policy issues.

The remainder of the paper is organized as follows. Section II provides some background information, including a very brief review of major changes in the exchange rate regime within the context of the country's overall transition to a market economy. The next section outlines the three key exchange rate concepts which will play a central part in the subsequent analysis, including measures of the nominal and real effective exchange rates compiled by the authors as part of the current study. Section IV then examines the major trends in nominal and real exchange rates during the study period, and section $\mathrm{V}$ analyses the interactions between the exchange rate regimes and a range of possible economic policy objectives, including nominal anchoring, inflation control, competitiveness and external balance, and transition to a well developed foreign exchange market. Finally, section VI provides a summary of the main findings and some concluding remarks.

\section{Background}

The economic reform process in Vietnam, often known as Doi Moi (renovation), has been extensively studied by many authors. For a very 
small sample of the literature of direct relevance to the present purposes, see Fforde and de Vylder (1996), Nguyen Duc-Tho and Bandara (1994), Nguyen Tri Hung (1999), Vo Tri Thanh et al. (2000), Pham Do Chi and Le Viet Duc (2003), Vo Dai Luoc (2004), and Pham Xuan Nam (2007). In brief, the pressures for change and reform which had been building up for a number of years came to a head in 1986, when the country was faced with an economic crisis characterized by persistent food shortages, worsening inflation, and large deficits in both the state budget and external trade. In response, the authorities undertook a series of decisive and fundamental measures to shift the economy from a bureaucratic, central planning model to a more market-oriented, decentralized system.

In line with the broader economic reform process, Vietnam's exchange rate (ER) regime has gone through major changes. Before 1989, there had been a complicated system of multiple fixed ERs: an official rate for foreign trade transactions, another for non-commercial transactions, a so-called internal settlement rate for the purpose of compensating export enterprises for their losses, and a separate rate for remittances received from overseas (Vo Tri Thanh et al. 2000; Nguyen Van Tien 2006). In March 1989, the multiple ERs were unified into a single official rate, set and announced by the State Bank of Vietnam (IMF 1996). Commercial banks were allowed to determine their buying and selling rates within a band of $+/-5$ per cent around the announced official rate, with a maximum bid-ask spread of 0.5 per cent. The official rate was subject to regular adjustments by the State Bank of Vietnam (SBV).

In late 1991, with the opening of two foreign exchange (FX) trading floors (in Ho Chi Minh City and Hanoi), the official rate became determined on a daily basis (IMF 1996). In setting this rate, the SBV would be guided to some extent by the previous day's closing rates on the two trading floors. Commercial banks were allowed to quote within a (narrowed) trading band of $+/-0.5$ per cent around the announced official rate. In October 1994, the trading floors were replaced by a more comprehensive and sophisticated interbank FX market, but there were no significant changes in the underlying ER setting mechanism.

Officially, February 1999 marked the beginning of a new approach to the setting of the announced ER. From this date, rather than setting an official rate that would be based partially on the previous average interbank rate, the SBV would simply announce that interbank rate without adjustment. (It is not clear exactly how this average rate is calculated.) Commercial banks were again allowed to determine their own selling and buying rates within a stipulated band. The band was fixed initially at +0.1 per cent (there was no lower band) but was then adjusted six times, to $+/-0.25$ per cent, $+/-0.5$ per cent, $+/-0.75$ per cent,$+/-1$ per cent; $+/-2$ per cent and $+/-3$ per cent in July 2002, December 2006, December 2007, March 2008, June 2008, and November 2008 respectively (see Figure 1).

The current ER regime has been described by the authorities as a managed float. In principle, under a managed float, the ER is determined by market forces and the government's influence on this rate is effected only through its purchases and sales in the FX market (Moosa 2004). In the case of Vietnam, the justification for the term "float" being in the above description is that the SBV no longer sets the official ER, but simply "notifies" the average interbank rate determined on the preceding business day through the interaction between supply and demand in the market. The regime is "managed" in that the ER can move only within a stipulated band, the SBV remains a major participant in the market, and various forms of administrative exchange controls are maintained.

\section{Key Exchange Rate Indices for Vietnam}

The ER that features most prominently in policy discussions in Vietnam is typically the nominal bilateral VND/USD rate, of which a rise corresponds to a weakening of the Vietnamese dong (VND). As Figure 2 shows, this ER increased from around 12 in 1985 and 607 in 1988 to around 10,000 in 1991 . It then stayed relatively stable until 1997, when it began to climb again, to 
FIGURE 1

Allowed Exchange Rate Band, 1992-2008

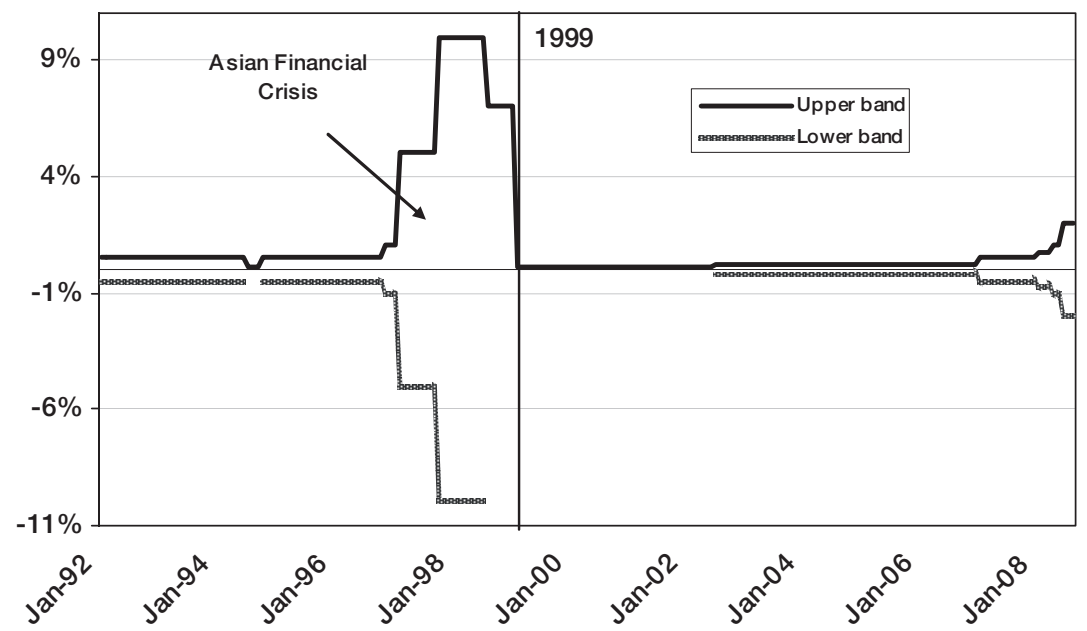

Note: There was no stipulated lower band for the periods Jul 94-Sept 94 and Aug 98-Jun 02. SourCE: Constructed by authors from various decisions by the SBV from 1991 to 2008.

FIGURE 2

Nominal VND/USD Rate, 1985-2007

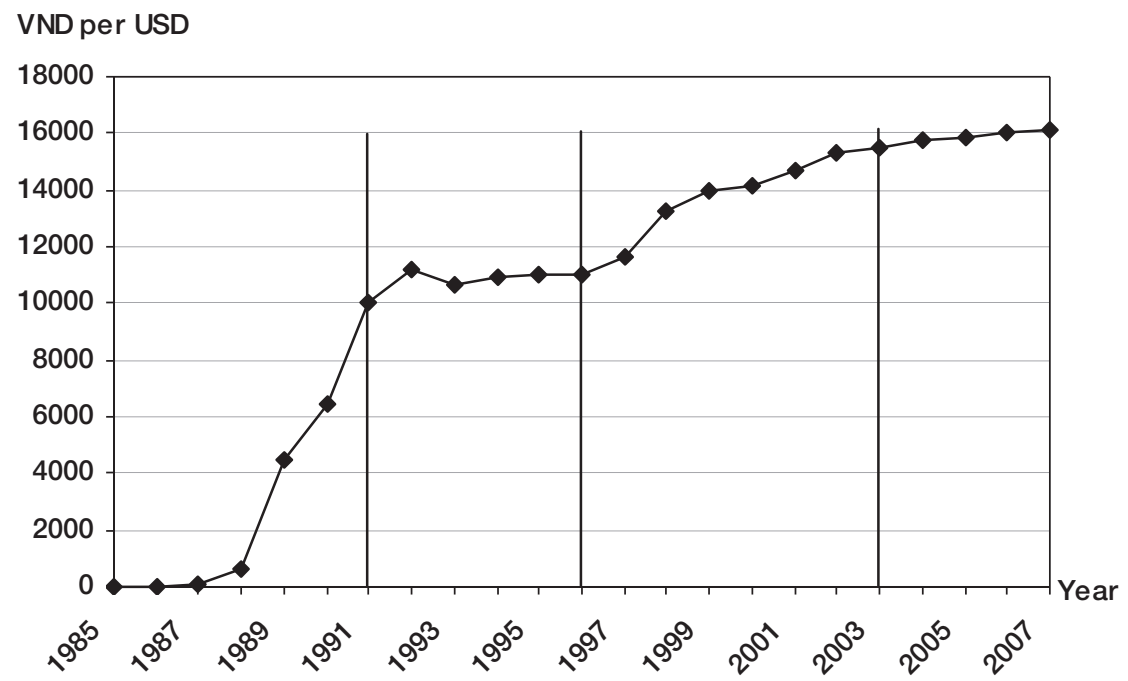

Note: Period average rate.

SOURCE: The IMF's International Financial Statistics (Online). 
around 15,500 in 2003. Over the period 20042007, this ER was again relatively stable.

In much of the analysis below, it will be useful to work mainly with the inverse of this ER, i.e., with the USD/VND rate, expressed as an index: a rise in this index corresponds to a strengthening of the VND. ${ }^{1}$ This is in keeping with our definitions of the nominal and real effective ERs: in each case, a rise in the ER index indicates an appreciation of the domestic currency.

Vietnam does not publish any official data for either the nominal effective exchange rate (NEER) or the real effective exchange rate (REER). The International Monetary Fund (IMF) does compile data series for both these variables, but mainly for internal use only. To our knowledge, it does not publish the relevant data for Vietnam, except for relatively short periods, such as 2001-2006, and on an annual basis only (IMF 2006d); see also the Appendix below.

In the literature, there have been a small number of efforts to compile these ERs, especially the REER, on an unofficial and relatively limited basis. For example, Nguyen Van Tien (2006) used annual data to calculate Vietnam's REER for the five-year period 1999-2004 on the basis of a trade basket consisting of four trading partners: Japan, China, the Euro zone and the United States. In a more comprehensive compilation, Tran Ngoc Tho et al. (2006) estimated REER for the period 19992005 on a quarterly basis and with a trade basket comprising seven trading partners: Singapore, Japan, the United States, China, Taiwan, France and Germany.

To facilitate the analysis in sections IV and V below, and also as a contribution to the available information in this area, we have compiled and made available (in the Appendix) an annual data set and a monthly data set for these two effective ERs. We define the NEER as the trade-weighted index of the value of the VND, i.e., the price of the domestic currency in terms of foreign currencies. Similarly, the REER is defined as the tradeweighted index of the inflation-adjusted price of the domestic currency in terms of foreign currencies. The exact formulae used to calculate these indices are presented in the Appendix.
While the two studies mentioned above calculated the REER on the basis of a trade basket that covers only about 50-60 per cent of Vietnam's total foreign trade, our calculations make use of a basket comprising twenty-five countries that account for about 90 per cent of total trade. This is in keeping with the international trend in recent years towards broader REER indices, which provide more reliable indications of changes in a country's external competitiveness (Richter and Svavarsson 2006). In common with recent international practice, the weighted averages are calculated as geometric averages. The trade weights are changed annually, and the resultant values are then chain-linked. Further details are provided in the Appendix.

For comparison, we have collected data for Vietnam's NEER and REER as found in various IMF publications (IMF 2000, 2003b, 2006b, $2006 d, 2007 b$ ). These are all annual data, and they relate to relatively short time periods and to different base years. As shown in the Appendix, we have reconciled and linked these various REER series into a combined twelve-year series which can be compared directly with our own estimates.

Visual inspection as well as an examination of the data suggests that, where the two series of estimates overlap, the data compiled by us track movements in the IMF series over time very well. This is probably a reflection of the fact that, in essence, our methods of compiling the data are very similar to the IMF methods, as described in its publications (Zanello and Desruelle 1997). It also lends some additional confidence to our estimates for the non-overlapping years and to our monthly estimates.

\section{Major Trends in Exchange Rates}

In this section we review the major trends displayed by the nominal USD/VND exchange rate (expressed as an index), as well as the NEER and REER for Vietnam, over the last two decades. (Recall that the definitions of all three indices imply that an increase in the index indicates a strengthening of the VND.) Annual data for NEER 
and REER are available only for 1992 onwards, and monthly data only for January 1995 onwards. Accordingly, Figure 3 illustrates annual movements in the three series for the period 1992-2007, while Figure 4 shows more details by using monthly data for the period January 1995-December 2007.

FIGURE 3

USD/VND Index, NEER and REER, 1992-2007

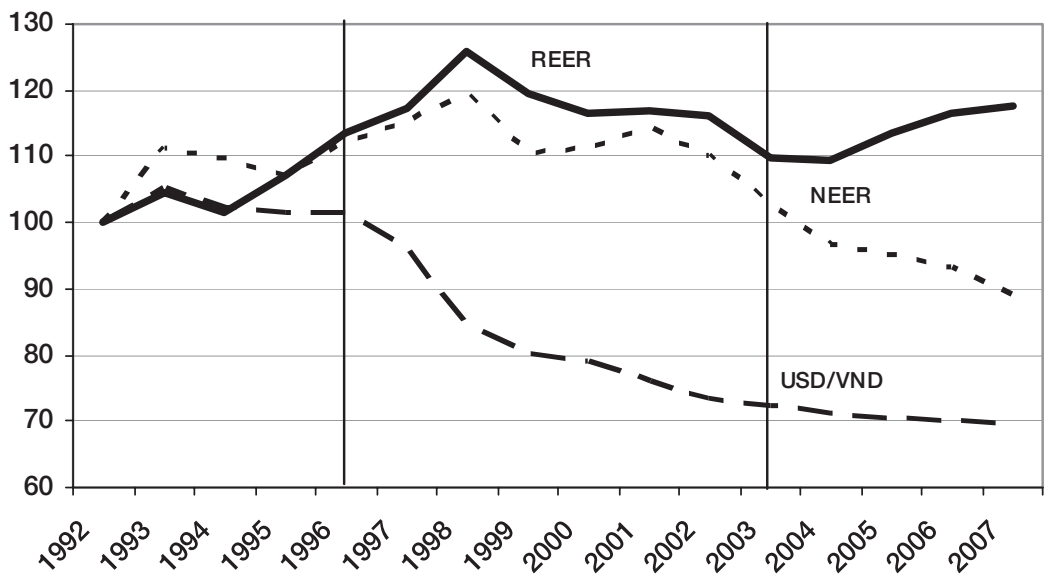

Note: Base year $1992=100$.

SourcE: The IMF's International Financial Statistics (Online); GSO.

FIGURE 4

Nominal USD/VND, NEER and REER, 1995-2007

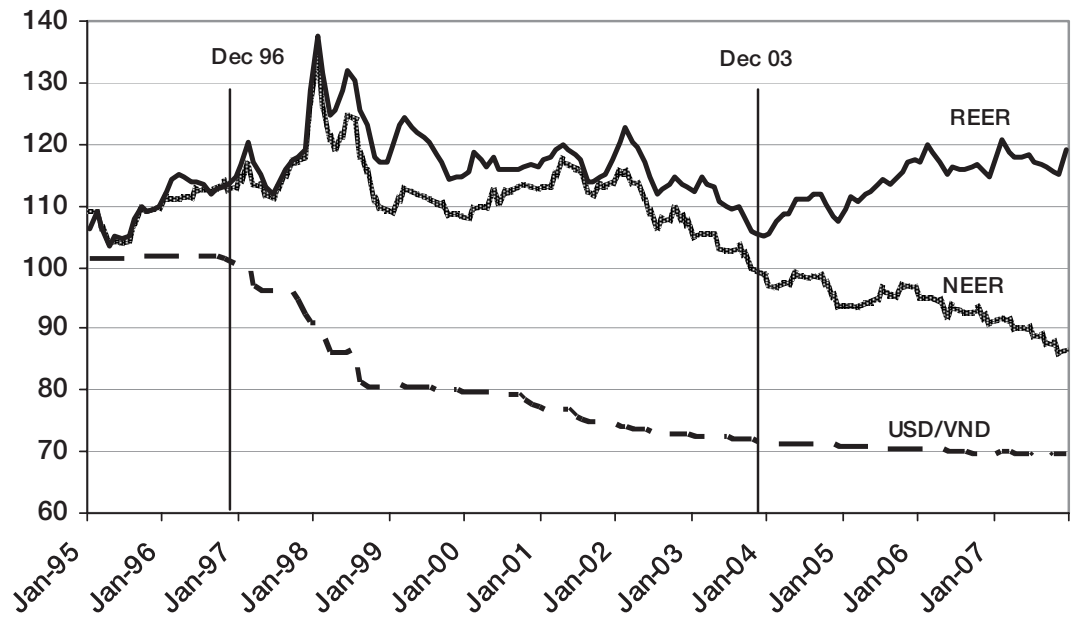

Note: Base year $1992=100$.

SOURCE: The IMF's International Financial Statistics (Online); GSO. 
From these figures, it can be seen that during the years 1992-96, and again during 2004-2007, the USD/VND rate was very stable while the NEER and REER experienced substantial changes. In contrast, during the initial Doi Moi years (1985-91, shown earlier in Figure 2) as well as the Asian financial crisis and its aftermath (1997-2003) the USD/VND rate indicated major weakenings of the VND against the USD. In what follows, it will be useful to organize the analysis to correspond to these four sub-periods.

\section{IV.1 The Initial Doi Moi Sub-period (1985-91)}

As mentioned above, during the second half of the 1980s, Vietnam undertook a series of sweeping reforms to liberalize the economy and tackle a major economic crisis, including a nearhyperinflation. Initially, these changes failed to reduce inflation (see Table 1). Indeed, they may have even contributed to a worsening at first: the inflation rate increased sharply from around 90 per cent p.a. in 1985 to triple-digit levels (361-455 per cent p.a.) during the next three years.

The authorities allowed the nominal value of the VND to fall by correspondingly large amounts.
Indeed, devaluations of the VND were so frequent, and the official ER began to converge so rapidly towards the unofficial rate in the parallel black market, that some authors consider the VND to be almost in a de facto float during these years (Le Van Te and Nguyen Quoc Khanh 2000). The period from March 1989 to August 1991 has often been described as a phase during which policy "followed" the market (IMF 1996, p. 36).

The large falls in the nominal value of the VND served to offset the impact of high inflation, thus halting and reversing the loss in external competitiveness: after having risen from around 152 in 1985 to 558 in 1987 , the real USD/VND exchange rate index fell to 83 in 1989 . Over the next several years (1990-92), this real ER then stabilized within the range 74 to 100 , with the nominal bilateral ER adjusting approximately in line with the purchasing power parity hypothesis.

The relative flexibility of the official VND/USD exchange rate during this sub-period, especially during 1988-90, was in line with the authorities' decision to adopt major changes which would place the economy on a transition path to a more market-oriented system. By 1991, however, when the official ER reached 10,000 VND per USD, it

TABLE 1

Inflation and Exchange Rates, 1985-1992

\begin{tabular}{lrrrrr}
\hline \multirow{2}{*}{ Year } & \multicolumn{2}{c}{ Inflation rate (\% p.a.) } & & \multicolumn{2}{c}{ Exchange rate } \\
\cline { 2 - 3 } \cline { 5 - 6 } & $V N$ & USA & & $V N D / U S D$ & Real index $^{\mathrm{a}}$ \\
\hline 1985 & 90 & 3.6 & & 11.9 & 151.6 \\
1986 & 455 & 1.8 & & 22.7 & 432.8 \\
1987 & 361 & 3.7 & & 78.3 & 558.2 \\
1988 & 374 & 4.1 & & 606.5 & 328.7 \\
1989 & 96 & 4.7 & & $4,464.0$ & 83.4 \\
1990 & 36 & 5.4 & & $6,482.8$ & 74.1 \\
1991 & 82 & 4.3 & & $10,037.0$ & 83.5 \\
1992 & 38 & 3.0 & & $11,202.2$ & 100.0 \\
\hline
\end{tabular}

Note: a. Real USD/VND exchange rate index, base $1992=100$.

Source: The IMF's International Financial Statistics (Online) and the IMF's World Economic Outlook Database (Online). 
had become much less flexible, and was soon stabilized around 11,000 VND per USD, a level that would essentially persist for a number of years.

\section{IV.2 The 1992-96 Sub-period}

From Figures 3 and 4, it can be seen clearly that the Vietnamese authorities were inclined to maintain a stable nominal USD/VND exchange rate during this sub-period, with only minor (and offsetting) movements in 1993 and 1994. As the U.S. dollar was generally strengthening against the currencies of many other trading partners of Vietnam, the country's NEER experienced a strong appreciation trend during this sub-period.

Initially (in 1993 and 1994) Vietnam's success in reducing its inflation rate, especially in comparison with the hyperinflation affecting Russia at the time, limited the resultant REER appreciation. In later years (1995 and 1996), however, as the inflation differential became unfavourable to Vietnam again, REER began to appreciate more rapidly. By 1996, both NEER and REER had appreciated by about 10 per cent compared with 1992, with the latter appreciation in particular indicating a sizeable loss of external competitiveness.

\section{IV.3 The Asian Financial Crisis and Trade Liberalization Sub-period (1997-2003)}

To the extent that the authorities might tend to focus on the nominal VND/USD rate, they would have been less concerned with changes in effective ERs and, therefore, rather less well prepared to deal with a shock which mainly affected the relationships between the USD and other ("thirdcountry") currencies rather than the bilateral VND/USD relationship. Indeed, when the Asian financial crisis broke out in 1997, the SBV's initial response was to broaden the band of allowed variations around the official VND/USD rate, rather than changing the official, central rate itself. The band was increased from $+/-1$ per cent to $+/-5$ per cent in February 1997, and then to $+/-10$ per cent in October 1997 (see Figure 1). As the commercial banks' selling rates for USD were typically quoted at the upper limit during this time, the above moves amounted to a series of rather reluctant and constrained devaluations of the VND against the USD, which did not fully eliminate the excess demand for USD.

These limited weakenings of the VND were also insufficient to match the precipitous falls in the values of a number of Asian currencies. As a result, both the NEER and REER of Vietnam continued to appreciate sharply. By January 1998, when these effective ERs reached their respective peaks, the country had lost almost 20 per cent in external competitiveness within two years.

After such large changes, the effective ERs may have attracted, at least for a time, greater attention than before. The USD/VND rate underwent several large-scale devaluations in 1998, sufficient to bring about a considerable depreciation in NEER, especially when Asian currencies began to stabilize against the USD. With domestic inflation being kept not too far out of line with trading partners, REER also depreciated, but to a lesser extent.

As of 2000 and 2001, the REER was still about 10 per cent to 15 per cent above its level in 1995 . The implied loss in competitiveness would have been substantial, especially in view of the trade liberalization measures that the country was about to implement to fulfil commitments under the ASEAN Free Trade Area (AFTA) and bilateral trade agreements. ${ }^{2}$ Faced with these special circumstances, and possibly for other reasons, from mid-2001 the authorities allowed the USD/ VND rate to resume its depreciation trend of about 2 per cent per annum. By 2003, the REER had fallen back to around 110, a level last prevailing before the Asian financial crisis.

\section{IV.4 The 2004-2007 Sub-period}

While the authorities displayed a willingness to make big adjustments in the value of the bilateral USD/VND exchange rate at special times, they apparently preferred to revert to an effective peg against the USD as soon as practicable after these contingencies. Indeed, the Governor of the SBV 
was quoted as publicly stating that the VND would not be allowed to depreciate by more than 1 per cent per annum during 2004-2005 (Camen 2006). As it turned out, the official USD/VND rate was again almost unchanged from January 2004 to December 2007.

As shown in Figures 3 and 4, NEER and REER generally diverged from each other during this sub-period. Because the VND was holding relatively steady against the USD, and the USD itself was weakening against many other currencies, the VND depreciated in nominal terms during most of this time. However, its high inflation rate more than offset this nominal depreciation tendency, so that the VND tended to appreciate in real terms. REER at the end of 2007 was about 10 per cent higher than at the beginning of 2004.

From the above review of the four sub-periods, it can be seen that during the past two decades, the authorities displayed ex post a clear preference for a stable nominal USD/VND exchange rate whenever that was feasible. Indeed, there were two sub-periods (1992-96, 2004-2007) when the VND was effectively pegged to the U.S. dollar, so that the path of NEER was dictated by the strength of the U.S. dollar relative to the currencies of other trading partners. Similarly, REER was determined residually, given the values of NEER and the inflation rate differential between Vietnam and its trading partners. As it happened, in both of the above sub-periods, REER tended to increase, indicating a loss of competitiveness.

\section{Implications for Policy Objectives}

There has been no clear official statement regarding the specific nature or priority rankings of the various economic and non-economic objectives pursued by the authorities while setting/ managing ERs and other monetary policy variables. Nevertheless, from economic theory and from observing other economies, it is possible to identify a number of key economic objectives which would have been of relevance to the country during this period. Further, from observation and analysis of historical data, it is possible to assess, ex post, the extent to which policy-making over time has been consistent with these objectives. In this section we examine the conduct of Vietnam's ER policy in terms of consistency with four possible economic policy objectives: nominal ER stability, inflation control, external competitiveness and external balance, and transition to a developed FX market.

\section{V.1 Nominal Exchange Rate Stability}

In the literature, the preference by some monetary authorities for a fixed ER regime is often provided a theoretical underpinning in terms of a stabilizing "nominal anchor", especially in the context of high inflation, rapid growth in monetary and credit aggregates, and large government budget deficits. Under such conditions, an ER peg relative to a major foreign currency could serve as a suitable anchor, especially in countries where the domestic government lacks a track record in policy-making that would establish its credibility with market participants.

It is not surprising that Vietnam has considered the USD a key nominal anchor. Some of its most important trading partners, such as China, Hong Kong, Singapore, Thailand and Malaysia, have generally preferred a stable ER relative to the USD. Vietnam's own experience in reducing inflation during the first half of the 1990s might also be seen as an example of the sort of benefits that an effective peg to the USD could bring.

How stable has the nominal USD/VND exchange rate been, then? One way to address this question is to ask how variable, or volatile, this rate has been. A simple measure of variability in a data series is its coefficient of variation $(\mathrm{CV})$, defined as ratio of the standard deviation to the mean. To highlight the volatility, or unpredictability, of the data, an alternative measure may also be used, namely the root mean square percentage error (RMSPE):

$$
R M S P E=100 \times \sqrt{\frac{1}{T} \sum_{t=1}^{T}\left(\frac{E_{t}-\hat{E}_{t}}{E_{t}}\right)^{2}}
$$


where $E_{t}$ represents the actual exchange rate in period $t$, and $\hat{E}_{t}$ the predicted exchange rate based on some suitable forecasting mechanism. A simple yet useful forecasting mechanism is the random walk model, where the actual $E_{t-1}$ value observed in period $t-1$ is used as the forecast value $\hat{E}_{t}$ for period $t$ (Dwyer, Nguyen, and Rajapakse 1996).

Our analysis is based on both the CV and RMSPE of the nominal VND/USD rate and
NEER, as well as comparable ERs for a number of other countries. The results suggest that these two measures of variability/volatility yield very similar findings in the current case. To conserve space, Table 2 presents a summary of the results based on the use of RMSPE only.

As might be expected from the discussion in section IV above, the results indicate that, except for the years of the Asian financial crisis (January 1997 to December 1998), the VND/USD rate was kept very stable compared with other bilateral

TABLE 2

Average Volatility (RMSPE) in Month-end Data

(In percentages)

\begin{tabular}{lcccccc}
\hline & $\begin{array}{c}\text { Jan 92- } \\
\text { Dec 94 }\end{array}$ & $\begin{array}{c}\text { Jan 95- } \\
\text { Dec 96 }\end{array}$ & $\begin{array}{c}\text { Jan 97- } \\
\text { Dec 98 }\end{array}$ & $\begin{array}{c}\text { Jan 99- } \\
\text { Dec 01 }\end{array}$ & $\begin{array}{l}\text { Dan 02- } \\
\text { Dec 03 }\end{array}$ & $\begin{array}{c}\text { Jan 04- } \\
\text { Dec 07 }\end{array}$ \\
\hline VND/USD & 0.7 & 0.2 & 2.0 & 0.4 & 0.2 & 0.2 \\
CNY/USD & 5.7 & 0.3 & 0.0 & 0.0 & 0.0 & 0.5 \\
THB/USD & 0.4 & 0.5 & 9.1 & 2.5 & 1.3 & 1.5 \\
JPY/USD & 2.6 & 3.7 & 5.0 & 2.9 & 2.2 & 2.3 \\
USD/GBP & 3.8 & 1.8 & 1.9 & 1.9 & 2.5 & 2.1 \\
NEER for VN & n.a & 1.3 & 3.3 & 1.2 & 1.3 & 0.9 \\
NEER for the US & 1.4 & 1.2 & 1.4 & 0.9 & 1.3 & 1.1 \\
NEER for China & 5.4 & 1.1 & 1.7 & 0.9 & 1.2 & 1.1 \\
\hline
\end{tabular}

Source: The IMF's International Financial Statistics (Online).

ERs. While the RMSPE of the VND/USD rate was in the range of $0.2-0.7$ per cent for most of the sub-periods considered, the JPY/USD and USD/ GBP rates recorded RMSPE of around 2 per cent or higher, and the THB/USD around 1 per cent or higher. It is interesting, however, to note that the RMSPE for the CNY/USD has been comparable to (and at times even lower than) that for the VND/USD. Thus, the volatility of the VND relative to the USD has been much lower than that of the currencies of the United Kingdom, Japan, or Thailand, but has not been very far out of line with China's currency.
Of course, the fact that the bilateral VND/USD rate has been relatively stable does not necessarily imply that the VND itself has been stable. On the contrary, the RMSPE figures reported in Table 2 indicate that Vietnam's NEER has been about as volatile as the NEER of the United States or of China. This result is consistent with the fact that both China and Vietnam have tended to use the USD as a nominal anchor: as the overall value of the latter moved up and down, so would the value of China's and Vietnam's currencies. 


\section{V.2 Inflation Control}

A theoretical rationale for maintaining a stable ER, or more generally for adopting a nominal anchor, is that this strategy may help the domestic authorities to reduce and stabilize inflation. Thus, in some context ER stability may not be an end in itself, but only a means to achieve the end-goal of inflation control.

In this connection, an ER peg can play its part by imposing discipline on the authorities' actions with regard to budget deficits and monetary growth rates, and by restoring confidence in the local currency and increasing policy credibility (Ohno 2003). In the context of a dollarized financial system, where a foreign currency such as the USD is widely accepted as an alternative medium of exchange, the advantages of a stable ER from the viewpoint of inflation control may be further enhanced. As Goujon (2006) pointed out, under dollarization, a depreciation of the domestic currency would increase the prices of not only traded goods but also of those non-traded goods that are priced in foreign currency, and would also directly add to the supply of money by increasing the domestic-currency value of foreign-currency assets held by domestic residents.

At the time when Vietnam began its transition to a market-oriented economy, the country was firmly in the grips of a traumatic bout of nearhyperinflation, and its financial system was already dollarized to a considerable extent — at least in a de facto sense (Nguyen Thi Hong 2002; Andreas and Nguyen Thanh Hai 2004). In these circumstances it would have been entirely appropriate to consider, among other things, the option of using the ER as a means to inflation control: the government needed to quickly stabilize inflation, restore policy credibility, and regain the public's trust in the value of the VND.

How consistent, then, has the setting of the ER been with inflation control? Figure 5 illustrates the evolution of the annual inflation rate since the mid-1980s; the picture it presents is dominated by the triple-digit rates recorded in the second half of the 1980s. That the country was then able to reduce and contain inflation to the vicinity of single-digit levels has generally been considered one of the most notable achievements of economic management under the Doi Moi process. As can be seen from Figure 6 (which shows monthly data for January 1991 onwards) the inflation rate has been kept generally below 10 per cent since January 1993. There was even a brief period of deflation during 2001 and 2002. Nevertheless, Vietnam's inflation rate has remained relatively high by international standards and, since 2004, has been on a rising trend.

A close examination of the data and circumstances prevailing at the time suggests that structural and institutional adjustments, rather than any nominal ER anchor, played the dominant part in sharply reducing the inflation rate during the years 1989-92. Indeed, as noted in subsection IV.1, the VND was repeatedly devalued against the USD by very large margins during this time.

Studies of the near-hyperinflation and efforts to tame it indicate that the main sources of inflationary pressures had been the removal of repressed demand, continuing supply bottlenecks, and extensive money creation to finance ballooning budget deficits (Nguyen Tri Hung 1999). Correspondingly, measures credited with having the biggest effects in countering inflation include the 1988 agrarian and land rights reform which boosted food production (Anderson 1998; Joei 2005), the abolition of inter-provincial trade barriers, and the rapid growth in production of consumer goods (assisted by large inflows of foreign capital). On the demand side, the implementation of positive real interest rates and more prudent fiscal and monetary policies, including the use of bond financing rather than money financing, has been considered a critical step (Nguyen Tri Hung 1999).

In most circumstances, an ER depreciation would tend to increase inflation, but at the time, this tendency was offset to some extent by the following mechanism: as the VND depreciated against the USD, domestic industries' competitiveness was restored, and losses incurred by state-owned enterprises were contained. This contributed to a slowdown in the growth of the budget deficit and the money supply. 
FIGURE 5

Annual Inflation Rate, 1985-2007

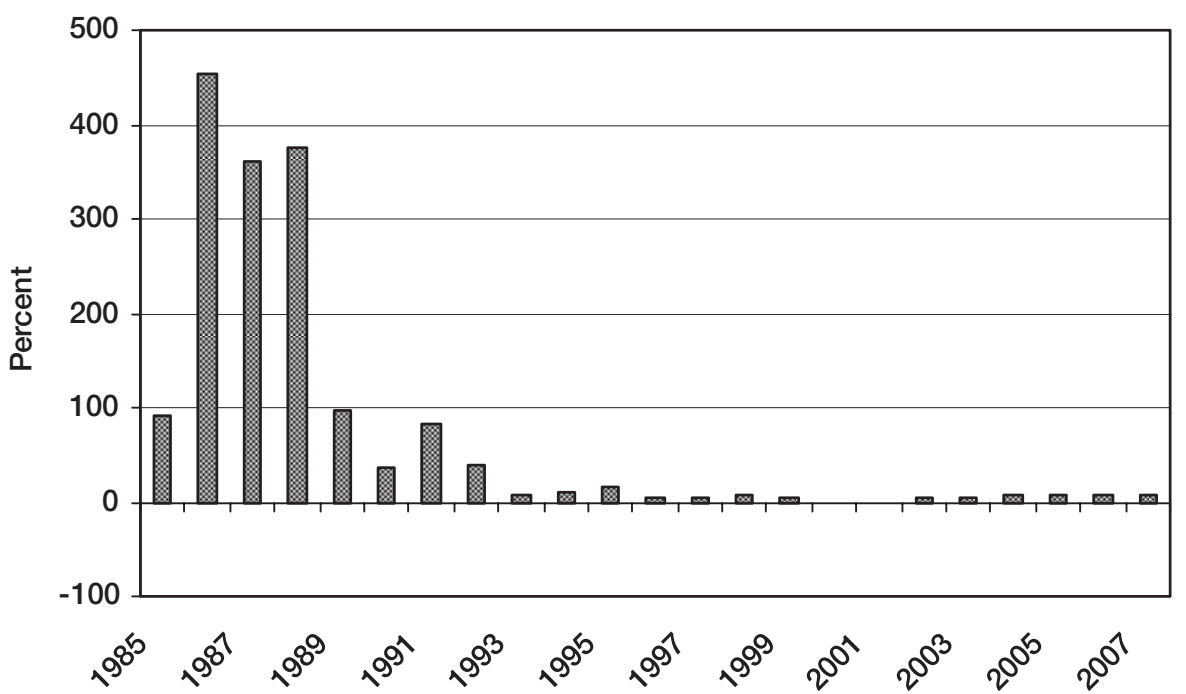

Source: The IMF's International Financial Statistics (Online); The IMF's World Economic Outlook Database (Online).

FIGURE 6

Inflation Rate, 1991-2007

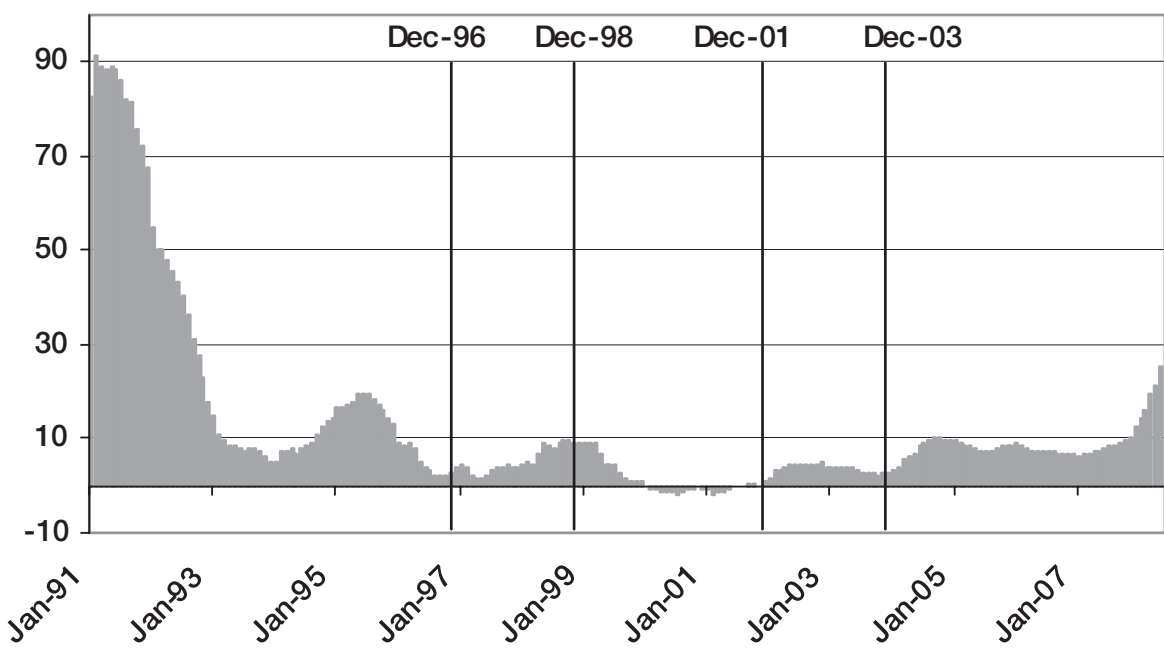

NotE: Inflation rate is calculated as the percentage rate of change over the corresponding month of the previous year. SOURCE: Nguyen (2002); SBV; GSO. 
Having concluded that a stable USD/VND exchange rate was not a dominant part of the inflation control efforts during the initial Doi Moi sub-period (1985-91), are we in a position to assess its role in subsequent sub-periods? In broad terms, it certainly appears that during the subperiod 1992-97, the stable USD/VND rate was associated with a remarkable reduction in the inflation rate. However, this apparent success of the nominal USD/VND anchor was frequently not repeated in subsequent sub-periods.

Examination of the data shows that during the Asian financial crisis and its aftermath (19972003) large falls in the nominal value of the VND relative to the USD did not result in any prolonged upsurge in inflation. Similarly, the latest subperiod (2004-2007) has been characterized by accelerating inflation despite a relatively stable USD/VND exchange rate.

Previous studies of inflation in Vietnam suggest that monetary and credit growth, supply shocks and inflation inertia have been more important than the nominal ER in determining the inflation rate. For example, supply shocks related to natural disasters and foreign price increases in 1994 boosted the relative prices of food prices, igniting a brief re-acceleration of inflation (IMF 1996; see also Figure 6). Similarly, the liberalization of previously administered prices for key commodities such as rice, cement, urea fertilizer, and construction steel during 2002-2004 and petroleum products since 2006 has contributed to inflationary pressures (IMF 2006c). More recently, the international food and oil price shocks of 2007 have had a similar impact (Hoang Ngoc Hoa 2008; Nguyen Quoc Hung 2008).

Research by the IMF (2006c) indicates that there exists a high degree of inflation inertia in Vietnam. It is estimated that a one-percentagepoint increase in the past inflation rate induces an increase of about 0.79 percentage points in inflation in the current period. This finding suggests that inflationary expectations adapt quickly to actual inflation outcomes, so that temporary supply and price shocks would tend to result in permanent increases in core inflation.
Ultimately, however, inflationary expectations can only be validated if monetary conditions accommodate them, and there is evidence that monetary growth has been a key driving force behind Vietnam's inflation process during much of the last two decades. For example, Vo Tri Thanh et al. (2000) used a short-run dynamic error correction model (ECM) to test if variables such as monetary aggregates, income (proxied by industrial output) and the nominal VND/USD rate were important determinants of inflation during the 1990s. Their results indicated that only monetary aggregates had a significant and positive impact on inflation; by contrast, the impact of changes in the ER became much weaker and insignificant during the second half of the decade.

Similarly, Camen (2006) employed a vector autoregression (VAR) model to conduct an exploratory analysis of the role of external variables, such as the U.S. money supply and commodity prices, as well as domestic factors in the determination of inflation in Vietnam during the period 1996-2005. The results suggested that the volume of domestic credit was the most important variable, accounting for about a quarter of the variations in the CPI - this exceeded the parts of the forecast error variance that were accounted for by commodity price and the nominal VND/USD rate. While the results of empirical studies such as these will always be subject to some caveats, together they do offer some formal support for the conclusion that the latter ER has not been a dominant determinant of inflation.

It is interesting to note that, in some years, the maintenance of a stable VND/USD rate actually contributed to inflationary pressures by adding to monetary growth. This occurred, for example, during 2003 and the years 2005-2007 when the SBV purchased large amounts of foreign exchange associated with capital inflows following the establishment of the stock market and a boom in the real estate market - most of these purchases were not sterilized (IMF 2003a, 2006a, 2006b, $2007 a)$. $^{3}$ Similarly, during 2002-2007, as the USD underwent substantial depreciations against other currencies, the VND also weakened in effective 
nominal terms, thus making imports more expensive and adding to inflation. ${ }^{4}$

In short, the authorities' apparent preference for a stable USD/VND ER has not been a major contributor to the determination of Vietnam's inflation rate, and in any case it has not been of great assistance to the country in trying to achieve a low and stable inflation rate.

\section{V.3 Competitiveness and Trade Balance}

A major potential problem with stable nominal ERs is that they may result in serious misalignments in the longer term, in that the real ER (and the country's external competitiveness) may drift far away from its equilibrium level, thus inducing substantial imbalances on the trade account. If the domestic inflation rate is generally higher than the foreign rate - and this, by and large, is the case for Vietnam - there will be a cumulative overvaluation of the domestic currency, causing a loss of competitiveness and, other things being equal, a deterioration in the trade balance (Ohno 2003).

As can be seen from Appendix Table A1 and Figures 3 and 4, during the two sub-periods when the nominal USD/VND exchange rate was kept stable (1992-96 and 2004-2007) the real effective exchange rate (REER) tended to increase - by about 10 per cent in each subperiod. ${ }^{5}$ By contrast, during the initial Doi Moi sub-period (1985-91) and the Asian financial crisis and its aftermath (1997-2003) the REER tended to reverse its upswing, so that by the end of each sub-period it had returned to approximately its initial level. From these observations, one would have to conclude that the conduct of ER policy has been less conducive to the preservation (or enhancement) of external competitiveness than to other policy objectives, and that changes to this observed pattern tended to occur only when the country was confronted with mounting evidence of a substantial loss in competitiveness, as in 1989 and 1998.

It is recognized that estimates of the real ER are imperfect measures of competitiveness, especially for low-income countries, due to data limitations, market imperfections, capital controls, etc. (Bella, Lewis, and Martin 2007). Accordingly, in assessing competitiveness for sixty-two developing countries, Bella, Lewis, and Martin (2007) made use of not only the REER but also indicators that are based on external sector outcomes, production costs, and the quality of the business environment. In their assessment, Vietnam's competitiveness declined between 2005, when it was included in the first decile of the low-income countries studied, and 2006, when it was ranked among the second decile. This finding is consistent with movements in the REER series compiled by us, thus providing some support for its use in the current analysis.

Other things being equal, a loss of competitiveness tends to worsen the trade balance. Figure 7 compare movements in the REER and trade balance for Vietnam; more detailed data on the country's external trade and foreign investment are presented in Table 3. In interpreting Figure 7, it should be kept in mind that prior to 2001 administrative measures were often used to affect trade flows directly, thereby moderating the relationship between real ER and trade balance to a varying extent.

For example, in response to the Asian financial crisis, the authorities imposed regulations aiming at (i) restricting the importation of consumer goods, and a complete, temporary halt to imports of certain goods; (ii) limiting the use of usance letters of credit in import transactions; and (iii) encouraging foreign invested enterprises to source inputs domestically while exporting outputs (Vo Tri Thanh et al. 2000; Nguyen Van Thanh 2004). These interventions partly explain the seemingly counterintuitive fact that the trade deficit declined during the years 1997 and 1998, even as the REER climbed to historically high levels. Similarly, as trade restrictions and foreign exchange controls were eased in 2001, and as reductions in tariffs began to take effect in line with AFTA commitments and with bilateral trade agreements (including one completed in November 2001 with the United States), the trade deficit increased sharply despite large falls in the REER in 2002 and 2003. 
FIGURE 7

REER and Trade Balance, 1996-2007

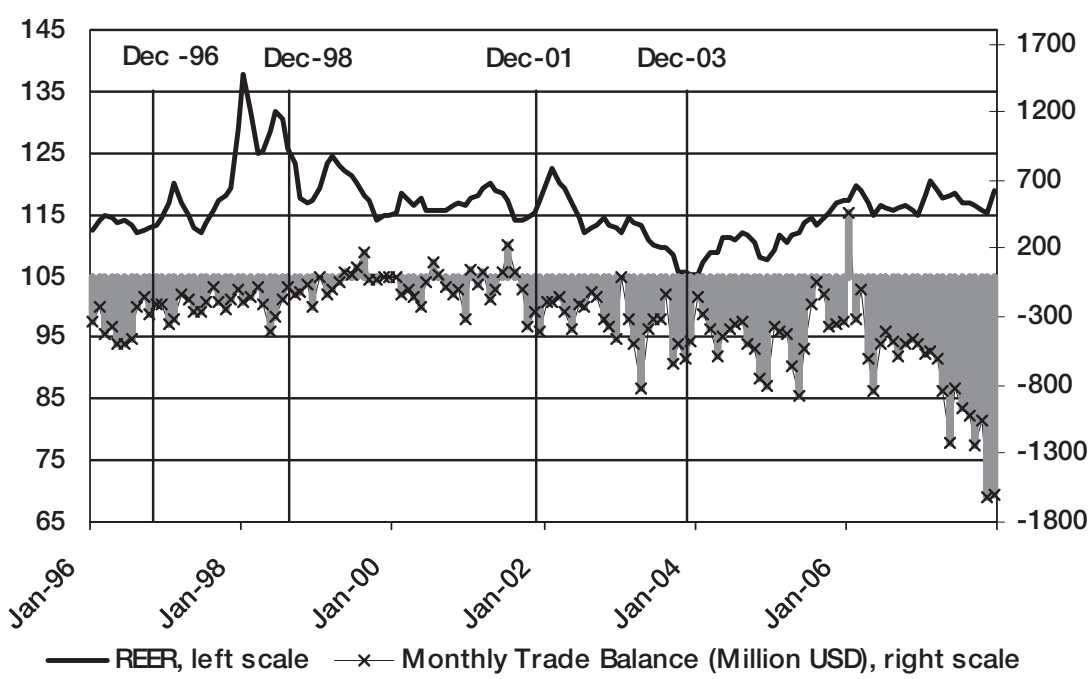

Note: Base year for REER is $1992=100$.

Source: The IMF's International Financial Statistics (Online); GSO.

Nevertheless, there was some evidence even before 2001 of a negative relationship between REER and trade balance, such as the decline in the trade deficit during 1990-92 following large falls in the REER. More importantly, during the subperiod 2004-2007, when trade flows were subject to far less administrative interference, there was a clear association between increases in the trade deficit and rises in the REER, although continuing trade liberalization would have contributed also to the worsening in the trade balance.

\section{V.4 Transition to a Developed Foreign Exchange Market}

In view of the general shift towards a more marketoriented economy, it is only to be expected that the authorities would wish to allow and indeed promote the development and enhancement of the FX market, provided this did not conflict too much with other, possibly more important, objectives. It is not surprising, therefore, that market arrangements supporting the ER setting mechanism have undergone major changes since the launching of the Doi Moi process in the mid-1980s.

Before March 1989, the official VND/USD exchange rate (for trade purposes) was administratively fixed for a long time at a level far lower than in the parallel (black) market, implying a massive overvaluation of the VND. In 1987 and 1988, for example, the parallel market rate was about five to six times the official rate (see Figure 8). Such artificial overvaluation of the domestic currency seriously hurt the competitiveness of export-related enterprises, many of which then qualified for government compensation or subsidies (Truong Van Phuoc 2006). On the import side, instead of allowing the most efficient industries and economic units to compete for the scarce foreign exchange, the authorities undertook the task of rationing the amount available administratively, with all the attendant inefficiencies (Le Quoc Ly 2004). 
TABLE 3

Foreign Trade and FDI, 1986-2007

\begin{tabular}{lrrrrrrr}
\hline & \multicolumn{3}{c}{ Trade (Million USD) } & & \multicolumn{2}{c}{ FDI Capital } \\
Ynflows
\end{tabular}

Source: The IMF's International Financial Statistics (Online); GSO.

After 1989, these problems were addressed through a series of large and frequent devaluations of the VND against the USD, which rapidly reduced the gap between the parallel market rate and the official rate to about 10 to 15 per cent or smaller; see Figures 8 and 9. Thus, during much of this time, the parallel market rate served as an approximate guide to the direction and extent of the necessary movement in the ER in order to bring it closer to equilibrium (IMF 1996).

The available data suggest that, during the period from late 1991 to early 2008, the parallel market premium generally remained stable and low, at around 1 per cent or less. An obvious exception was the time of the Asian financial crisis (1997-98) when the premium again surged to around 10 to 20 per cent. Overall, it would appear that policy and institutional changes permitted market forces to play a more important part in determining the ER during this period than previously.

The opening in late 1991 of the two FX trading floors and the establishment in 1994 of the interbank FX market represent important steps in the development of the FX market. These 
FIGURE 8

Ratio of Parallel-Market to Official Exchange Rate, 1985-89

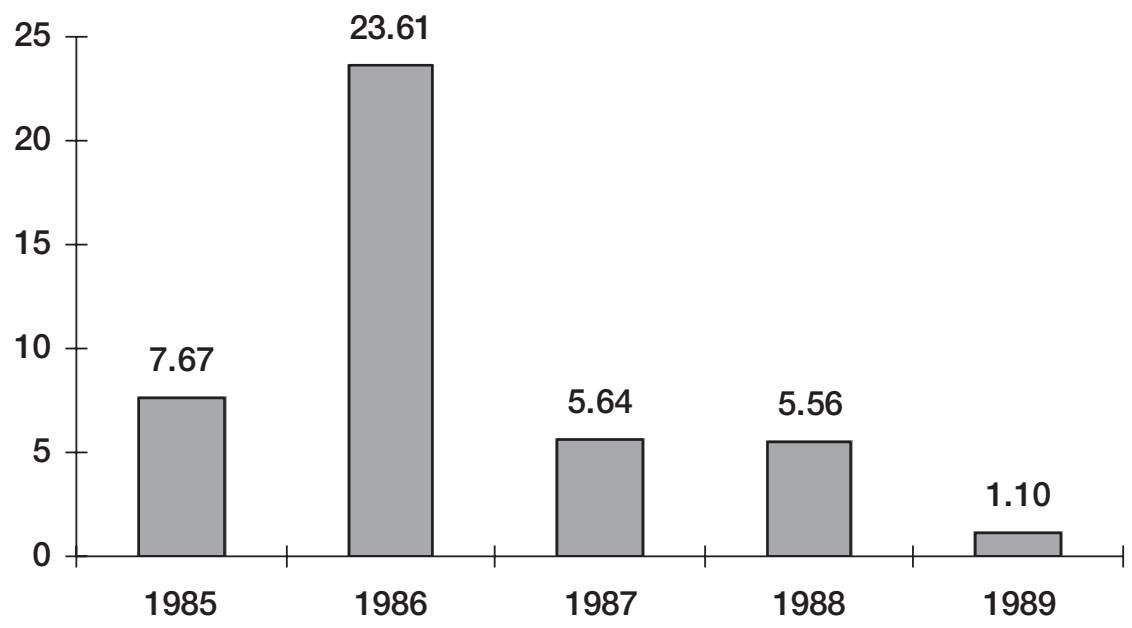

Source: Le Van The and Nguyen Quoc Khanh (2000).

FIGURE 9

Gap between Official Exchange Rate and Parallel Market Rate

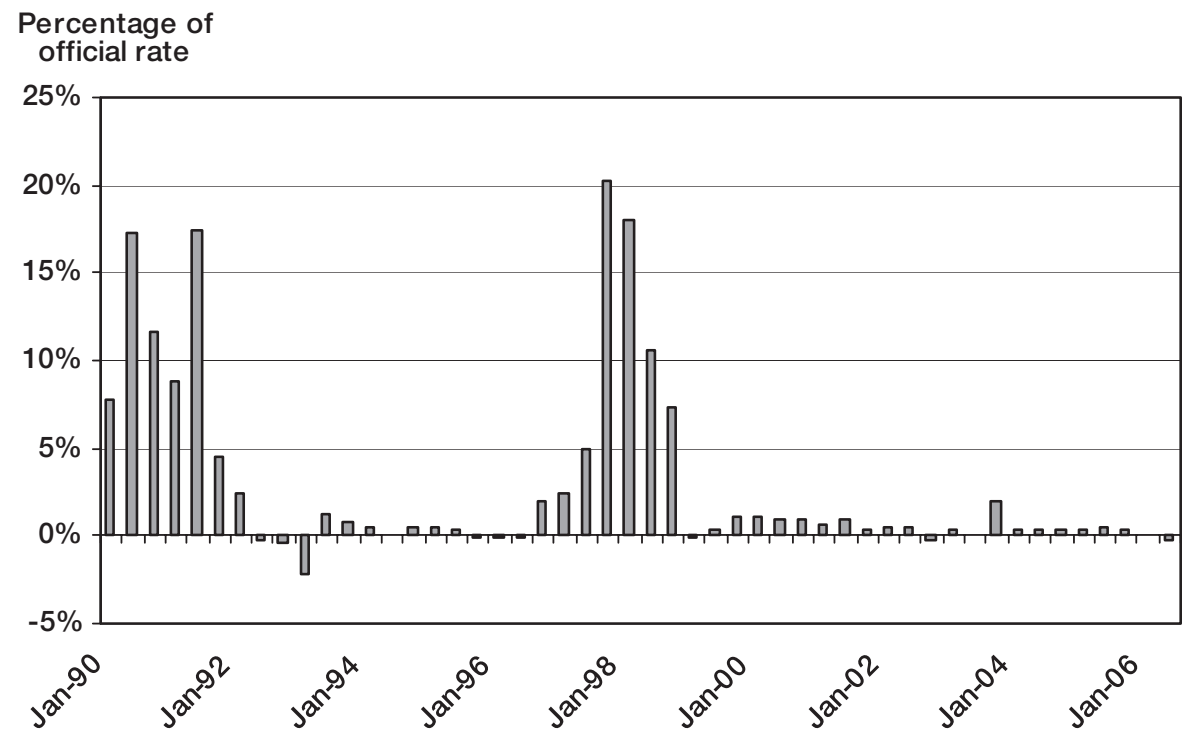

SOURCE: SBV. 
organized centres allowed transactions to be conducted much more efficiently. They served to lower transaction costs and reflected far more faithfully the relative strengths of supply and demand than the informal (and in principle illegal) parallel market.

Since the interbank market began, Vietnam's FX market has operated as a two-tier system, comprising a client/retail market and an interbank market. The former mainly serves corporate and individual customers, while the latter facilitates trading among the banks. Under this system, the SBV no longer conducts transactions with businesses directly, but instead focuses on conducting transactions in the interbank market, as required, to achieve its objectives.

Despite the considerable progress already achieved towards liberalizing and developing the FX market, to date it remains rather shallow and under-developed (Nguyen Tran Phuc and Nguyen Duc-Tho 2009). In 2006, average daily turnover in the FX market of Vietnam was around US\$0.15 billion. By comparison, in 2007 the corresponding figure was US\$1.85 billion for Indonesia, US $\$ 3.88$ billion for Thailand, and US\$35 billion for Singapore. The low turnover figure for Vietnam suggests that the FX market there has captured only a relatively small proportion of the total supply and demand for foreign exchange. In 2006, the country's FX market turnover amounted to only about 60 per cent of its total export and import value. By contrast, the FX turnoverinternational trade ratio in 2007 was 310, 480 and 2,220 per cent for Indonesia, Thailand and Singapore, respectively.

Although the necessary framework has been put in place for transactions in FX derivatives to be conducted, actual trading in forward and option contracts remains very thin, and there are no future contracts. The underlying reason for this slow pace of development is the fact that the key VND/USD exchange rate has been managed to such an extent that, in general, it exhibits little volatility and market participants perceive little FX risk.

It is interesting to note in this connection that, at times, the risk of ER changes has been transformed into a risk of illiquidity, in that it may become impossible for a bank customer to buy or sell foreign currency at the quoted rates. Thus, when there is an excess demand for USD, and the quoted ER is already at its highest allowable level (as observed in April to July 2008; see Figure 10), supply simply dries up, as banks and other market participants have little incentive to sell.

In practice, some banks and their customers have found ways to get around this problem, such as the payment of fees or commissions on related transactions (Hai-Ly 2008). Alternatively, the customer must resort to transacting in the informal parallel market. Evidently there are considerable deadweight losses involved in such cases.

If, as the SBV characterizes, the current ER regime is a (managed) float, how could it maintain stable ERs for such lengthy periods? The answer lies, of course, in the "managed" part of the managed float concept. The SBV was the dominant participant under the trading-floor system, and it has remained dominant in the interbank market, typically buying and selling large amounts of foreign currency to establish its preferred ER level on a daily basis (Vo Tri Thanh et al. 2000).

In short, efforts have been made to allow market forces to play a greater role than in the past in the process of ER determination, but those efforts have been constrained by an apparent preference for a stable VND/USD exchange rate. The country's ER policy has been less conducive to achieving transition to a developed and free FX market than to attaining ER stability.

\section{Conclusion}

In this paper we have provided a synthesis of some of the available information and data regarding Vietnam's ER regime and an analysis of whether, and to what extent, the conduct of ER policy has been consistent with the pursuit of a number of economic policy objectives. The authorities did not always make clear what the priority rankings of their objectives were. Nevertheless, it is possible to identify a shortlist of 
FIGURE 10

Official Rate, Its Bounds, Commercial Bank Selling Rates, and

Parallel Market Selling Rates, Jan-July 08

\section{Daily VND/USD}

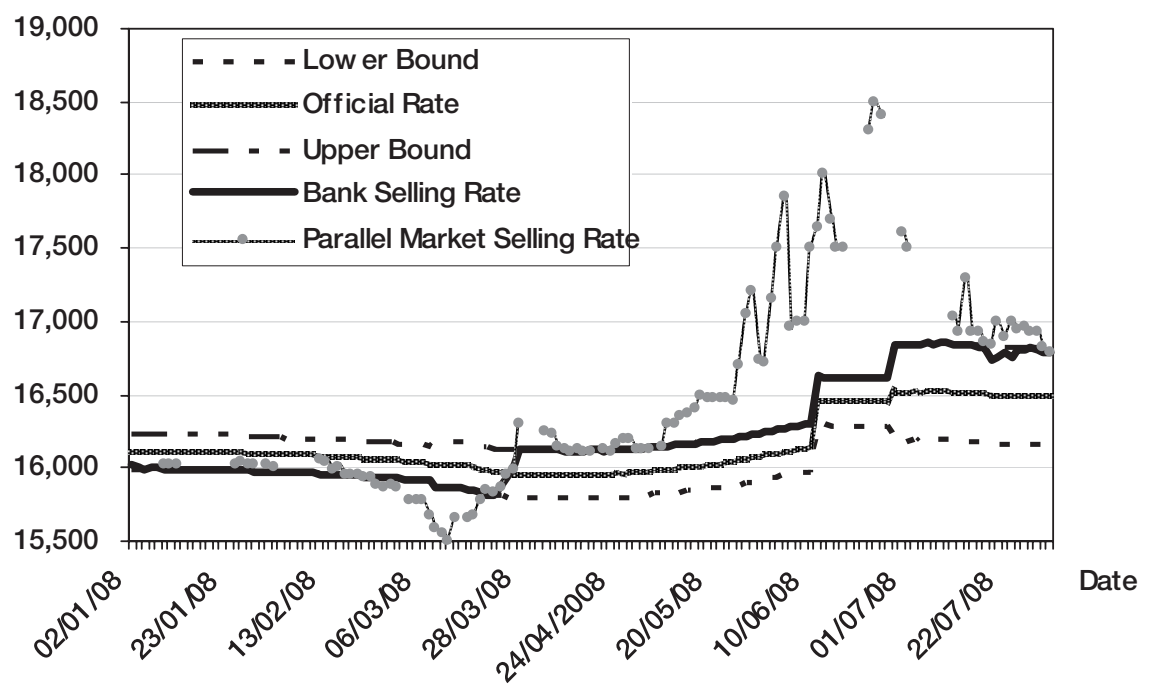

SourCE: SBV, the Banking Association of Vietnam, Vietcombank, and VNexpress.

economic objectives that would have been of some relevance to most other economies in similar economic circumstances. These include ER stability, inflation control, international competitiveness and external balance, and transition to a developed FX market.

Despite the many changes that have been implemented in the ER setting arrangements, the SBV has retained a dominant role in the FX market, and administrative mechanisms have been maintained, such that the country's ER regime has been more "managed" than it has been a "float". In essence, the key VND/USD exchange rate has remained rather sticky.

From the historical movements of this bilateral ER as well as the NEER and REER, it can be seen ex post that the authorities apparently preferred a stable VND/USD rate. There were periods — such as the launch of the Doi Moi process, the Asian financial crisis, and the implementation of trade liberalization measures - when, arguably, the authorities had little choice but to allow large movements in this bilateral rate. Nevertheless, it would appear that whenever such contingencies had passed, the authorities would return to a relatively stable VND/USD rate.

As a result of this emphasis on the bilateral VND/USD rate, the overall value of the Vietnamese currency in nominal terms (NEER) as well as in real terms (REER) has often become an endogenous, rather than policy, variable. As it happened, this means that there have been large losses in the country's external competitiveness, which would add to the current account deficit. Similarly, stability in the official VND/USD rate and administrative controls have not been conducive to more rapid development of the FX market.

Finally, it would seem from an examination of the available evidence that stability in this ER is 
definitely not a sufficient condition for low and stable inflation, and perhaps not a necessary condition either. There have been periods when inflation was successfully reduced and kept under control, despite a depreciating VND. Conversely, there have also been periods when a stable VND/ USD rate was accompanied by an upward trend in the inflation rate.
Our analysis suggests that, at the very least, greater attention should be paid to movements in the effective ERs, especially the REER. Doing so would reduce the risk that the country's external competitiveness may be seriously eroded by a stable or appreciating NEER in combination with increasing inflation differentials between the domestic country and its trading partners.

\section{APPENDIX \\ Computation of NEER and REER for Vietnam}

\section{Formulae}

The effective exchange rate indices used in the main paper are defined in foreign currency terms and are estimated by the geometric mean method as per the following formulae:

$$
\begin{gathered}
N E E R_{t}=\prod_{j=1}^{n}\left(e_{j t}\right)^{W_{j t}} \\
\operatorname{REER}_{t}=\prod_{j=1}^{n}\left(e_{j t} \frac{P_{t}}{P_{j t}}\right)^{W_{j t}}
\end{gathered}
$$

where:

- $N E E R_{t}$ is the nominal effective exchange rate of the home country at time $t$;

- $R E E R_{t}$ is the real effective exchange rate of the home country at time $t$;

- $n$ is the number of trading-partner currencies in the trade basket;

- $e_{j t}$ is the nominal bilateral exchange rate relative to currency $j$, measured as the number of units of currency $j$ per unit of the domestic currency, and expressed as an index;

- $W_{j t}$ is the weight assigned to currency $j$ at time $t$, reflecting the contribution of the country of currency $j$ to the home country's foreign trade; and

- $P_{t}$ is the domestic price index at time $t$ and $P_{j t}$ is the price index of foreign country $j$ at time $t$.

As both indices are defined in foreign-currency terms, an increase in their value indicates an appreciation of the home currency.

\section{Choice of Base Year, Currency Basket and Weights}

Year 1992 is selected to be the base year for our calculations, due mainly to availability of data. This year was also the first year that the Vietnamese economy can be regarded as having re-established some stability after the sweeping changes associated with the Doi Moi economic reform process during the latter half of the 1980s.

The currency basket includes twenty-five trading partners: six ASEAN member countries (Cambodia, Indonesia, Malaysia, Singapore, Thailand, the Philippines), seven Euro zone countries (Belgium, France, Germany, Italy, the Netherlands, Spain, Switzerland) and twelve other countries/economies: Argentina, Australia, Canada, China, India, Hong Kong, Japan, South Korea, Russia, Taiwan, the United Kingdom, and the United States.

Each selected trading partner accounted for at least 0.5 per cent of Vietnam's total foreign trade during the latest ten years. The basket covered about 90 per cent of this total trade in every year since 1996. For present purposes, the trade weights are re-calculated annually, and the resultant values are chain-linked. 
Data Sources and Usage

- The CPI is the only price index available for Vietnam and for several trading partners in the currency basket. Therefore, we use CPI data in our computation of REER.

- Annual data are available for the computation of the NEER and REER indices for the period 1992-2007.

- Monthly data are available for the computation of the NEER and REER indices for the period 1995-2007.

- In general, data for period-average exchange rates (between a particular currency and the U.S. dollar) and data for period-average CPI are obtained directly from the IMF's International Financial Statistics (IFS) online.

- Data for Taiwan are collected from the website of the National Statistics of Taiwan, the ROC.

- Trade data for Vietnam are obtained from the General Statistics Office. Data on Vietnam's CPI and bilateral VND/ USD exchange rate are obtained from Vietnamese sources such as the SBV and the GSO, and are used to crosscheck with those obtained from the IFS or as supplementary sources to fill some missing observations in the relevant IFS data series.

- Some adjustments and processing of the obtained data are made:

- CPI data are adjusted to reflect year 1992 being the base year instead of year 2000;

- For Australia, as monthly CPI data are not available, they are interpolated using the quarterly data;

- For China, as CPI data are provided in the forms of changes over the corresponding period of the previous year, these data are used to calculate monthly and annual CPI indices;

- For countries in the Euro zone, the "synthetic" values of the nominal USD/EUR corresponding to each country are computed backward to 1992 on the basis of the conversion rates published by the European Central Bank as of 31 December 1998 and the corresponding bilateral rates with the US dollar during the 1992-98 period; and

- The exchange rates between the VND and a particular currency in the basket are calculated as cross rates, based on their rates with the U.S. dollar.

\section{Resultant Estimates and Comparison with IMF Estimates}

Tables A1 to A3 present the annual and monthly values of the NEER and REER as calculated by the authors.

For comparison, Table A4 present data obtained from a number of IMF publications for the REER over the period 1995-2006. The combined and linked series based on these IMF data, in column (e), shows similar movements over time to those of the series compiled by the authors, reported in column (g). The similarities are shown graphically in Figure A1.

In another comparison, Figure A2 contrasts our NEER and REER estimates with those used by the IMF staff in a country report for Vietnam (IMF 2006b). It can be seen clearly that, for the years for which data are available in both data sets, our NEER and REER series generally tracked movements in the IMF series quite well.

TABLE A1

Annual NEER and REER, 1992-2007

$($ Base year $1992=100)$

\begin{tabular}{lrl}
\hline Year & NEER & REER \\
\hline 1992 & 100.00 & 100.00 \\
1993 & 111.32 & 104.65 \\
1994 & 109.81 & 101.47 \\
1995 & 107.09 & 107.15 \\
1996 & 112.10 & 113.50 \\
1997 & 115.48 & 117.21 \\
1998 & 119.42 & 125.93 \\
1999 & 110.37 & 119.36 \\
2000 & 111.32 & 116.55 \\
2001 & 114.24 & 117.06 \\
2002 & 110.25 & 116.07 \\
2003 & 102.70 & 109.83 \\
2004 & 96.69 & 109.39 \\
2005 & 95.10 & 113.35 \\
2006 & 93.19 & 116.60 \\
2007 & 89.16 & 117.69 \\
\hline
\end{tabular}


TABLE A2

Monthly NEER, 1995-2007

$(1992=100)$

\begin{tabular}{|c|c|c|c|c|c|c|c|}
\hline Month & NEER & Month & NEER & Month & NEER & Month & $N E E R$ \\
\hline Jan-00 & 109.0 & Apr-98 & 119.7 & Jul-01 & 115.7 & Oct-04 & 97.4 \\
\hline Feb-95 & 109.0 & May-98 & 121.2 & Aug-01 & 112.4 & Nov-04 & 95.1 \\
\hline Mar-95 & 106.3 & Jun-98 & 124.6 & Sep-01 & 111.9 & Dec-04 & 93.9 \\
\hline Apr-95 & 103.7 & Jul-98 & 124.0 & Oct-01 & 113.0 & Jan-05 & 93.6 \\
\hline May-95 & 104.2 & Aug-98 & 118.1 & Nov-01 & 113.1 & Feb-05 & 93.7 \\
\hline Jun-95 & 103.8 & Sep-98 & 115.7 & Dec-01 & 113.9 & Mar-05 & 93.3 \\
\hline Jul-95 & 104.3 & Oct-98 & 110.5 & Jan-02 & 115.0 & Apr-05 & 94.1 \\
\hline Aug-95 & 107.1 & Nov-98 & 109.9 & Feb-02 & 115.1 & May-05 & 94.1 \\
\hline Sep-95 & 109.5 & Dec-98 & 109.0 & Mar-02 & 113.7 & Jun-05 & 95.1 \\
\hline Oct-95 & 109.0 & Jan-99 & 109.0 & Apr-02 & 113.5 & Jul-05 & 96.1 \\
\hline Nov-95 & 109.4 & Feb-99 & 110.7 & May-02 & 111.1 & Aug-05 & 95.2 \\
\hline Dec-95 & 109.7 & Mar-99 & 112.6 & Jun-02 & 108.8 & Sep-05 & 95.5 \\
\hline Jan-96 & 111.1 & Apr-99 & 112.3 & Jul-02 & 106.7 & Oct-05 & 96.5 \\
\hline Feb-96 & 111.0 & May-99 & 112.0 & Aug-02 & 107.4 & Nov-05 & 97.1 \\
\hline Mar-96 & 111.0 & Jun-99 & 111.6 & Sep-02 & 107.9 & Dec-05 & 96.7 \\
\hline Apr-96 & 111.4 & Jul-99 & 111.1 & Oct-02 & 108.9 & Jan-06 & 94.9 \\
\hline May-96 & 111.4 & Aug-99 & 110.1 & Nov-02 & 107.8 & Feb-06 & 95.1 \\
\hline Jun-96 & 112.4 & Sep-99 & 109.9 & Dec-02 & 107.1 & Mar-06 & 95.1 \\
\hline Jul-96 & 112.6 & Oct-99 & 108.5 & Jan-03 & 105.2 & Apr-06 & 94.1 \\
\hline Aug-96 & 112.2 & Nov-99 & 108.5 & Feb-03 & 105.3 & Мay-06 & 92.2 \\
\hline Sep-96 & 112.8 & Dec-99 & 108.1 & Mar-03 & 105.4 & Jun-06 & 93.2 \\
\hline Oct-96 & 113.3 & Jan-00 & 107.9 & Apr-03 & 105.3 & Jul-06 & 93.0 \\
\hline Nov-96 & 112.8 & Feb-00 & 109.5 & May-03 & 102.9 & Aug-06 & 92.7 \\
\hline Dec-96 & 113.2 & Mar-00 & 109.7 & Jun-03 & 102.5 & Sep-06 & 92.7 \\
\hline Jan-97 & 114.3 & Apr-00 & 109.8 & Jul-03 & 102.8 & Oct-06 & 92.8 \\
\hline Feb-97 & 116.1 & May-00 & 111.9 & Aug-03 & 103.2 & Nov-06 & 91.6 \\
\hline Mar-97 & 113.5 & Jun-00 & 110.8 & Sep-03 & 102.0 & Dec-06 & 90.8 \\
\hline Apr-97 & 113.0 & Jul-00 & 111.8 & Oct-03 & 100.0 & Jan-07 & 91.5 \\
\hline May-97 & 111.8 & Aug-00 & 112.1 & Nov- 03 & 99.5 & Feb-07 & 91.7 \\
\hline Jun-97 & 111.1 & Sep-00 & 112.9 & Dec-03 & 98.4 & Mar-07 & 91.0 \\
\hline Jul-97 & 112.8 & Oct-00 & 113.5 & Jan-04 & 97.1 & Apr-07 & 90.2 \\
\hline Aug-97 & 115.3 & Nov-00 & 113.2 & Feb-04 & 96.4 & May-07 & 90.0 \\
\hline Sep-97 & 116.7 & Dec-00 & 112.8 & Mar-04 & 97.2 & Jun-07 & 89.9 \\
\hline Oct-97 & 116.9 & Jan-01 & 113.0 & Apr-04 & 97.3 & Jul-07 & 88.8 \\
\hline Nov-97 & 117.7 & Feb-01 & 112.9 & May-04 & 98.8 & Aug-07 & 88.6 \\
\hline Dec-97 & 126.6 & Mar-01 & 115.3 & Jun-04 & 98.4 & Sep-07 & 87.9 \\
\hline Jan-98 & 133.8 & Apr-01 & 117.2 & Jul-04 & 98.1 & Oct-07 & 87.3 \\
\hline Feb-98 & 125.8 & May-01 & 116.5 & Aug-04 & 98.4 & Nov-07 & 86.3 \\
\hline Mar-98 & 120.7 & Jun-01 & 116.0 & Sep-04 & 98.2 & Dec-07 & 86.8 \\
\hline
\end{tabular}


TABLE A3

Monthly REER, 1995-2007

$(1992=100)$

\begin{tabular}{|c|c|c|c|c|c|c|c|}
\hline Month & NEER & Month & NEER & Month & NEER & Month & NEER \\
\hline Jan-00 & 106.3 & Apr-98 & 125.4 & Jul-01 & 117.4 & Oct-04 & 110.3 \\
\hline Feb-95 & 109.2 & May-98 & 128.6 & Aug-01 & 114.1 & Nov-04 & 108.1 \\
\hline Mar-95 & 106.0 & Jun-98 & 131.8 & Sep-01 & 114.0 & Dec-04 & 107.4 \\
\hline Apr-95 & 103.4 & Jul-98 & 130.5 & Oct-01 & 114.6 & Jan-05 & 109.3 \\
\hline May-95 & 105.0 & Aug-98 & 125.5 & Nov-01 & 115.2 & Feb-05 & 111.4 \\
\hline Jun-95 & 104.8 & Sep-98 & 123.3 & Dec-01 & 117.3 & Mar-05 & 110.6 \\
\hline Jul-95 & 105.1 & Oct-98 & 117.7 & Jan-02 & 120.3 & Apr-05 & 111.7 \\
\hline Aug-95 & 107.7 & Nov-98 & 116.9 & Feb-02 & 122.6 & May-05 & 112.2 \\
\hline Sep-95 & 109.8 & Dec-98 & 117.2 & Mar-02 & 120.2 & Jun-05 & 113.5 \\
\hline Oct-95 & 109.2 & Jan-99 & 119.4 & Apr-02 & 119.4 & Jul-05 & 114.3 \\
\hline Nov-95 & 109.4 & Feb-99 & 123.2 & May-02 & 117.0 & Aug-05 & 113.4 \\
\hline Dec-95 & 109.8 & Mar-99 & 124.4 & Jun-02 & 114.5 & Sep-05 & 114.4 \\
\hline Jan-96 & 112.3 & Apr-99 & 122.9 & Jul-02 & 111.9 & Oct-05 & 115.4 \\
\hline Feb-96 & 114.2 & Мay-99 & 122.1 & Aug-02 & 112.8 & Nov-05 & 116.9 \\
\hline Mar-96 & 114.9 & Jun-99 & 121.2 & Sep-02 & 113.3 & Dec-05 & 117.3 \\
\hline Apr-96 & 114.6 & Jul-99 & 120.2 & Oct- 02 & 114.5 & Jan-06 & 117.3 \\
\hline May-96 & 113.7 & Aug-99 & 118.2 & Nov- 02 & 113.4 & Feb-06 & 119.8 \\
\hline Jun-96 & 113.9 & Sep-99 & 117.2 & Dec-02 & 112.9 & Mar-06 & 118.9 \\
\hline Jul-96 & 113.3 & Oct-99 & 114.1 & Jan-03 & 112.2 & Apr-06 & 117.0 \\
\hline Aug-96 & 111.8 & Nov-99 & 114.7 & Feb-03 & 114.6 & May-06 & 115.0 \\
\hline Sep-96 & 112.5 & Dec-99 & 114.7 & Mar-03 & 113.6 & Jun-06 & 116.3 \\
\hline Oct-96 & 112.9 & Jan-00 & 115.4 & Apr-03 & 113.1 & Jul-06 & 115.9 \\
\hline Nov-96 & 113.3 & Feb-00 & 118.6 & May-03 & 110.6 & Aug-06 & 115.8 \\
\hline Dec-96 & 114.6 & Mar-00 & 117.4 & Jun-03 & 109.9 & Sep-06 & 116.2 \\
\hline Jan-97 & 116.8 & Apr-00 & 116.5 & Jul-03 & 109.6 & Oct-06 & 116.6 \\
\hline Feb-97 & 120.2 & May-00 & 117.9 & Aug-03 & 109.7 & Nov-06 & 115.6 \\
\hline Mar-97 & 116.9 & Jun-00 & 115.8 & Sep-03 & 108.3 & Dec-06 & 114.9 \\
\hline Apr-97 & 115.0 & Jul-00 & 115.7 & Oct- 03 & 105.6 & Jan-07 & 118.1 \\
\hline May-97 & 112.9 & Aug-00 & 115.8 & Nov-03 & 105.5 & Feb-07 & 120.5 \\
\hline Jun-97 & 111.8 & Sep-00 & 115.8 & Dec-03 & 105.0 & Mar-07 & 118.8 \\
\hline Jul-97 & 113.6 & Oct-00 & 116.4 & Jan-04 & 105.2 & Apr-07 & 117.7 \\
\hline Aug-97 & 115.8 & Nov-00 & 116.8 & Feb-04 & 107.3 & May-07 & 118.0 \\
\hline Sep-97 & 117.4 & Dec-00 & 116.5 & Mar-04 & 108.8 & Jun-07 & 118.3 \\
\hline Oct-97 & 117.9 & Jan-01 & 117.6 & Apr-04 & 108.7 & Jul-07 & 117.0 \\
\hline Nov-97 & 119.1 & Feb-01 & 117.9 & May-04 & 111.2 & Aug-07 & 117.1 \\
\hline Dec-97 & 128.9 & Mar-01 & 119.3 & Jun-04 & 111.2 & Sep-07 & 116.6 \\
\hline Jan-98 & 137.7 & Apr-01 & 119.9 & Jul-04 & 110.9 & Oct-07 & 115.8 \\
\hline Feb-98 & 131.8 & May-01 & 119.1 & Aug-04 & 111.9 & Nov-07 & 115.3 \\
\hline Mar-98 & 124.9 & Jun-01 & 118.4 & Sep-04 & 111.7 & Dec-07 & 119.0 \\
\hline
\end{tabular}


TABLE A4

Comparison of REER Estimates Compiled by the IMF and the Present Study

\begin{tabular}{cccccccc}
\hline Source & $(a)$ & $(b)$ & $(c)$ & $(d)$ & $(e)$ & $(f)$ & $(g)$ \\
\hline Base yr & 2000 & 1997 & 1990 & 1990 & 2000 & 1992 & 2000 \\
\hline 1995 & & & & 122.9 & 92.6 & 107.2 & 91.9 \\
1996 & & & & 131.1 & 98.8 & 113.5 & 97.4 \\
1997 & & & 134.7 & 135.4 & 102.0 & 117.2 & 100.6 \\
1998 & & & 145.5 & 146.5 & 110.2 & 125.9 & 108.0 \\
1999 & & & 136.0 & 137.4 & 103.0 & 119.4 & 102.4 \\
2000 & & 132.4 & 132.0 & & 100.0 & 116.6 & 100.0 \\
2001 & 100.1 & 133.5 & 133.1 & & 100.1 & 117.1 & 100.4 \\
2002 & 98.3 & 132.7 & 132.3 & & 98.3 & 116.1 & 99.6 \\
2003 & 90.6 & 126.2 & & & 90.6 & 109.8 & 94.2 \\
2004 & 89.3 & 126.3 & & & 89.3 & 109.4 & 93.9 \\
2005 & 93.2 & & & & 93.2 & 113.4 & 97.3 \\
2006 & 96.7 & & & & 96.7 & 116.6 & 100.0 \\
\hline
\end{tabular}

NoTES:
(a) IMF (2006d, 2007b).
(b) IMF $(2006 d)$.
(c) $\operatorname{IMF}(2003 b)$.
(d) IMF (2000).
(e) IMF combined and linked.
(f) Estimates by present authors.
(g) As for (f) but re-expressed.

FIGURE A1

Comparison of REER Estimates by IMF and Present Study

\section{REER Estimates from IMF and N\&N}

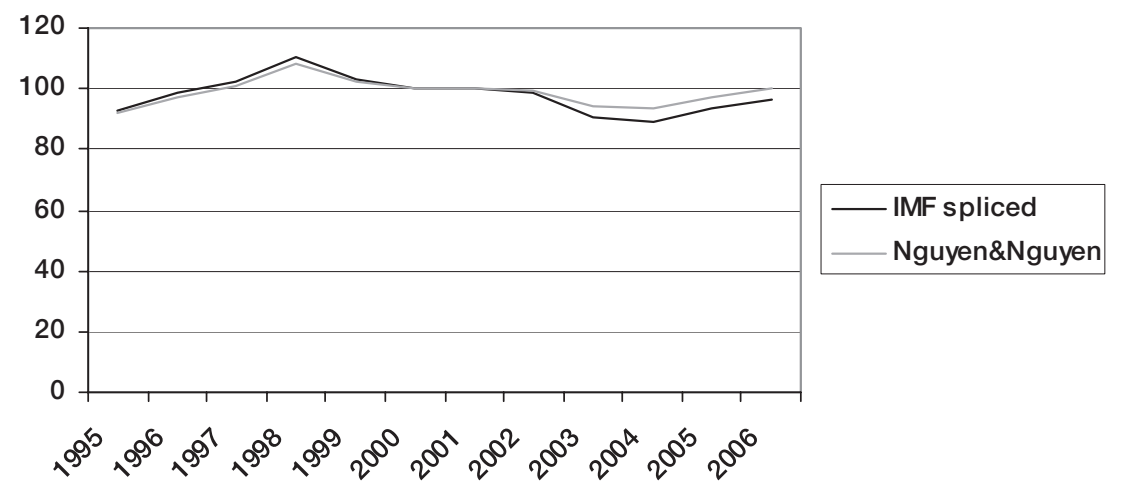


FIGURE A2

Comparison with the Indices Provided in an IMF Report

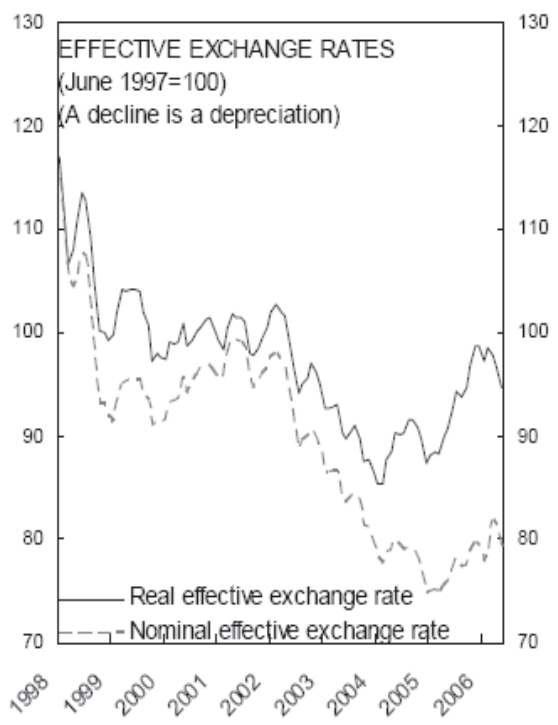

(a) NEER and REER computed by IMF (Source: IMF 2006b)

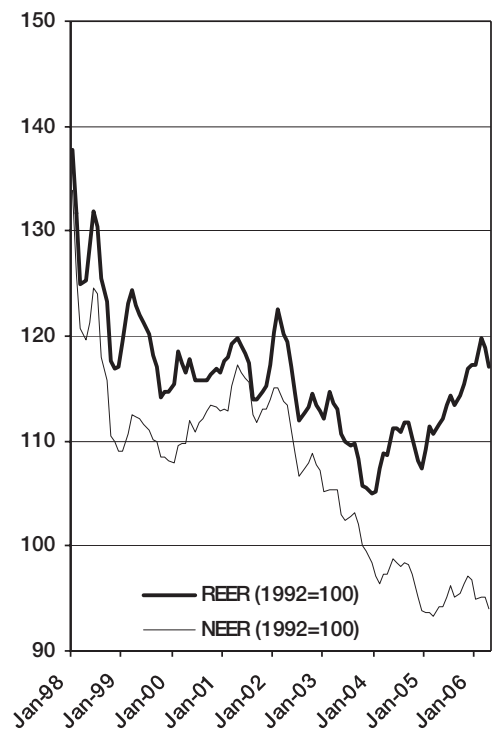

(b) NEER and REER computed by the authors

\section{NOTES}

The authors wish to thank Tarlok Singh, Jay Bandaralage, and anonymous $A E B$ referees for their helpful comments, but accept responsibility for any shortcomings which may remain.

1. To describe some historical episodes, however, it will be convenient to cite the values of the VND/USD rate for consistency with usual practice.

2. In 2001, foreign exchange controls were relaxed: Foreign invested enterprises were allowed to buy foreign exchange from commercial banks for their imports, and the foreign exchange surrender requirement applicable to exporters was reduced from 50 per cent to 40 per cent. Further, starting from early 2001, reductions in tariffs were made in accordance with the commitments under AFTA so that tariffs on ninety-seven tariff lines included in the Inclusion List would be reduced to at most 20 per cent by 2003 and 0 to 5 per cent by 2006. In addition, quantitative restrictions on several important imported items were eliminated and replaced by tariffs (IMF 2002).

3. This is an example of the "inconsistent trinity", in that of the three well-known policy goals - full freedom of cross-border capital mobility, ER stability, and monetary policy independence — only two goals can be pursued at any given time (Eiteman et al. 2008).

4. By this, we do not mean to suggest that a free float would have necessarily resulted in a stable NEER, but merely to point out some consequences of a stable VND/USD rate.

5. Again, it is important to keep in mind that, during certain years such as 2003 and 2005-2007 when there were strong capital inflows, a free float could have resulted in an even larger appreciation of the REER than actually occurred, because the NEER would have been subject to considerable pressure to appreciate. The main point we are trying to make here is simply that a stable VND/USD was not conducive to preserving external competitiveness (REER stability). 


\section{REFERENCES}

Anderson, K. Vietnam's Transforming Economy and WTO Accession: Implication for Agriculture and Rural Development. Adelaide: University of Adelaide, 1998.

Andreas, H. and Nguyen-Thanh-Hai. "Dollarization in Vietnam”. Working Paper, Kelley School of Business, Indiana University, Bloomington, 2004.

Bella, G. D., M. Lewis, and A. Martin. "Assessing Competitiveness and Real Exchange Rate Misalignment in LowIncome Countries”. IMF Working Paper No. WP07/201. International Monetary Fund, Washington, D.C., 2007.

Camen, U. "Monetary Policy in Vietnam: The Case of a Transition Country". BIS Working Paper No. 31. Bank for International Settlement, Basel, 2006.

Dwyer, L., Nguyen, D. T., and S. Rajapakse. “The Volatility of Australia's Exchange Rate: A Synthesis". Economic Analysis and Policy 26, no. 1 (1996): 25-44.

Eiteman, D., K. Daly, S. Rath, A. Stonehill, and M. Moffett. Multinational Business Finance. Frenchs Forest, NSW: Pearson Education Australia, 2008.

Fforde, A. and S. D. Vylder. From Plan to Market: The Economic Transition in Vietnam. Boulder, CO: Westview Press, 1996.

Frieden, J., P. Ghezzi, and E. Stein. "Politics and Exchange Rates: A Cross-Country Approach". In The Currency Game Exchange Rate Politics in Latin America, edited by J. Frieden and E. Stein, pp. 21-63. Washington, D.C.: Inter-American Development Bank, 2001.

Goujon, M. "Fighting Inflation in a Dollarized Economy: the Case of Vietnam". Journal of Comparative Economics 34 , no. 3 (2006): 564-81.

Hai-Ly. "Kich ban nao cho ty gia" [What Scenarios Are for the Exchange Rate]. Saigon Times, 17 July 2008 , pp. 10-11.

Ho, C. and R. N. McCauley. "Living with Flexible Exchange Rates: Issues and Recent Experience in Inflation Targeting Emerging Market Economies”. BIS Working Paper No. 130. Bank for International Settlements, Basel, 2003.

Hoang-Ngoc-Hoa. "Nhung giai phap vi mo ve chinh sach tai chinh - tien te - gia ca gop phan khac phuc lam phat cao dam bao phat trien kinh te ben vung" [Macroeconomic Measures in Terms of Financial, Monetary and Price Policies for Overcoming High Inflation and Ensuring Sustainable Economic Development]. Tap Chi Ngan Hang (Banking Journal), no. 7/2008. <http://www.sbv.gov.vn/vn/home/tintapchi.jsp?tin=454>. Accessed 10 June 2008.

IMF. Vietnam Transition to a Market Economy. IMF Occasional Paper No. 135. Washington, D.C.: International Monetary Fund, 1996.

- "Vietnam: Statistical Appendix and Background Notes". IMF Staff Country Report No. 00/116. International Monetary Fund February, Washington, D.C., 2000.

. "Vietnam: Selected Issues and Statistical Appendix". IMF Country Report No. 02/5. International Monetary Fund, Washington, D.C., 2002.

—. "Vietnam: 2003 Article IV Consultation — Staff Report; Staff Statement; Public Information Notice on the Executive Board Discussion; and Statement by the Executive Director for Vietnam". IMF Country Report No. 03/380. International Monetary Fund, Washington, D.C., $2003 a$.

_ . "Vietnam: Statistical Appendix". IMF Country Report No. 03/382. International Monetary Fund, Washington, D.C.: $2003 b$.

— . "Vietnam: 2005 Article IV Consultation — Staff Report; Staff Statement; Public Information Notice on the Executive Board Discussion; and Statement by the Executive Director for Vietnam". IMF Country Report No. 06/22. International Monetary Fund, Washington, D.C., 2006a.

—. "Vietnam: 2006 Article IV Consultation — Staff Report; Staff Statement; Public Information Notice on the Executive Board Discussion; and Statement by the Executive Director for Vietnam". IMF Country Report No. 06/421. International Monetary Fund, Washington, D.C., $2006 b$.

_. "Vietnam: Selected Issues". IMF Country Report No. 06/442. International Monetary Fund, Washington, D.C., $2006 c$.

. "Vietnam: Statistical Appendix". IMF Country Report No. 06/52. International Monetary Fund, Washington, D.C., 2006d.

."Vietnam: 2007 Article IV Consultation — Staff Report; Staff Supplement and Statement; Public Information Notice on the Executive Board Discussion; and Statement by the Executive Director for Vietnam". IMF Country Report No. 07/387. International Monetary Fund, Washington, D.C., 2007a.

_ "Vietnam: Statistical Appendix". IMF Country Report No. 07/386. International Monetary Fund, Washington, D.C., $2007 b$. 
Joei, B. T. K. "Vietnam in the World of the 1990s". In The Vietnamese Economy and its Transformation to an Open Market System, edited by W. T. Alpert, pp. 164-99. New York: M.E. Sharpe, 2005.

Le-Quoc-Ly. Ty gia hoi doai - Nhung van de ly luan va thuc tien dieu hanh o Vietnam [Exchange Rate: Theoretical Issues and Practice of Managing in Vietnam]. Hanoi: Statistics Publisher, 2004.

Le-Van-Te and Nguyen-Quoc-Khanh. Mot so Van de ve Chinh sach Ty gia Hoi doai cho Muc tieu Phat trien Kinh te Viet Nam [Some Issues Regarding the Exchange Rate Policy for Economic Development of Vietnam]. Ho Chi Minh City: Statistics Publisher, 2000.

Moosa, I. A. International Finance: An Analytical Approach. 2nd ed. Sydney: McGraw-Hill, 2004.

Nguyen-Duc-Tho and J. S. Bandara. "Economic Reforms in Vietnam". In Economic Reform, Liberalisation and Trade in the Asia-Pacific Region, edited by D. T. Nguyen and K. C. Roy, pp. 116-38. New Delhi: Wiley Eastern Ltd, 1994.

Nguyen-Quoc-Hung. "Chong lam phat bang chinh sach ty gia: Mot cong cu manh can phat huy" [Fighting Inflation by Exchange Rate Policy: A Strong Instrument Should Be Promoted]. Tap Chi Ngan Hang (Banking Journal), no. 4 (2008), www.sbv.gov.vn/vn/tintuc/tcnh/nguyendinhtrung/tin/tapchi_2008_04_14_090103.doc?tin=451. Accessed 10 June 2008.

Nguyen-Thi-Hong. "Dollarization of Financial Assets and Liabilities of the Household Sector, the Enterprises Sector and the Banking Sector in Vietnam". Paper presented at the JICA-State Bank of Vietnam Joint Research Project Workshop on "Dollarization and its effect on monetary and foreign exchange rate policies and the development of financial system, Vietnam, Lao PDR and Cambodia”, Hanoi, 5 July 2002.

Nguyen-Tran-Phuc and Nguyen-Duc-Tho. "The Foreign Exchange Market in Vietnam, 1986-2008: A Market Microstructure Approach”. Working Paper, Griffith University Brisbane, 2009.

Nguyen-Tri-Hung. "The Inflation of Vietnam in Transition". CAS Discussion Paper No. 22. Centre for International Management and Development Antwerp, Centre for ASEAN Studies, 1999.

Nguyen-Van-Thanh. "Tac dong cua chinh sach quan ly ngoai hoi va dieu hanh ty gia den thi truong ngoai hoi va xuat khau" [Impacts of Exchange Rate Policy and Management of Exchange Rate on Foreign Exchange Market and Export]. In Quan ly ngoai hoi va dieu hanh ty gia o Viet Nam [Foreign Exchange Control and Management of Exchange Rate in Vietnam], edited by Le-Quoc-Ly, pp. 224-50. Hanoi: Statistics Publisher, 2004.

Nguyen-Van-Tien. Tai chinh quoc te [International Finance]. Hanoi: Statistics Publisher, 2006.

Ohno, K. "Exchange Rate Management of Vietnam: Re-examination of Policy Goals and Modality". Vietnam Development Forum, 2003. <http://www.vdf.org.vn/publications.html>. Accessed 20 February 2008.

Pham-Do-Chi and Le-Viet-Duc. "A Decade of Doi Moi in Restrospect: 1989-99”. In The Vietnamese Economy: Awakening the Dormant Dragon, edited by B. Tran-Nam and C. D. Pham, pp. 30-52. London: RoutledgeCurzon, 2003.

Pham-Xuan-Nam. "Vietnam: 20 Years of Socioeconomic Renewal". Social Sciences Information Review 1, no. 1 (2007): 3-10.

Richter, G. Y. and D. Svavarsson. "Effective Exchange Rate Calculations". Monetary Bulletin 8, no. 2 (2006): 77-90.

Tran-Ngoc-Tho, Nguyen-Thi-Ngoc-Trang, Truong-Van-Phuoc, Vu-Viet-Quang and Nguyen-Khac-Quoc-Bao. "Phuong phap tiep can co che dieu hanh ty gia o Viet Nam" [Methodology Approaching the Exchange Rate Mechanism in Vietnam]. Working Paper No. B2005-22-96, University of Economics of Ho Chi Minh City, Ho Chi Minh City, 2006.

Truong-Van-Phuoc. "The Choice of Relevant Regime and the Management of Exchange Rate Policy of Vietnam under the Process of Economic Integration”. Ph.D. dissertation, University of Economics of Ho Chi Minh City, 2006.

Vo-Dai-Luoc. "Vietnam's Economic Renovation Along Socialist-Oriented Market Economy". Paper presented at the International Policy Conference on Transition Economies, Hanoi, 2004.

Vo-Tri-Thanh, Dinh-Hien-Minh, Do-Xuan-Truong, Hoang-Van-Thanh and Pham-Chi-Quang. "Exchange Rate Arrangement in Vietnam: Information Cotent and Policy Options". East Asian Development Network (EADN), Individual Research Project, 2000.

Zanello, A. and D. Desruelle. A Primer on IMF's Information Notices System. IMF Working Paper No. WP97/7. International Monetary Fund, Washington, D.C., 1997.

Nguyen Tran Phuc is a Ph.D. candidate in the Department of Accounting, Finance and Economics, Griffith Business School, Griffith University, Australia.

Nguyen Duc-Tho is Professor of Economics in the Department of Accounting, Finance and Economics, Griffith Business School, Griffith University, Australia. 